\title{
Long-term phosphate fertilization, mycorrhizal inoculation and historical land use influence on soybean growth and $P$ uptake
}

\author{
Adubação fosfatada, inoculação micorrízica e histórico de uso do \\ solo no crescimento da soja e absorção de $P$
}

\author{
Paulo Emílio Ferreira da Motta ${ }^{1}$, José Oswaldo Siqueira², Bruno Teixeira Ribeiro ${ }^{3 *}$, \\ Lloyd Darrell Norton ${ }^{4}$, Sérgio Henrique Godinho Silva ${ }^{5}$, Nilton Curi ${ }^{3}$
}

\author{
${ }^{1}$ Empresa Brasileira de Pesquisa Agropecuária/Embrapa Solos, Rio de Janeiro, RJ, Brasil \\ ${ }^{2}$ Instituto Tecnológico Vale, Belém, PA, Brasil \\ 3Universidade Federal de Lavras/UFLA, Departamento de Ciência do Solo/DCS, Lavras, MG, Brasil \\ ${ }^{4}$ USDA-ARS National Soil Erosion Research Laboratory, West Lafayette, IN, USA \\ ${ }^{5}$ Universidade Federal de Lavras/UFLA, Lavras, MG, Brasil \\ *Corresponding author: brunoribeiro@dcs.ufla.br \\ Received in April 15, 2016 and approved in June 16, 2016
}

\begin{abstract}
Phosphorus is a key-nutrient in the fertility management of highly weathered tropical soils. So, this work was carried out with the objective of evaluating the influence of the interaction between $\mathrm{P}$ doses, mycorrhizal inoculation and historical land use on soybean growth and $\mathrm{P}$ uptake in five Latosols (Oxisols) with contrasting chemical, physical and mineralogical properties under a continuous long-term phosphate fertilization (more than 15 years). The plants were cultivated in $4.5 \mathrm{~L}$-plastic pots containing $4 \mathrm{~kg}$ of soil in a completely randomized design, four replications and $2 \times 2 \times 2$ factorial scheme with two P doses; and with or without mycorrhizal inoculation; and soils cultivated for long periods and non-cultivated (under native vegetation). There were two cultivations of ten weeks each. Shoot dry mass, P content and accumulation in the shoot dry mass were evaluated after each cultivation period. The cultivation history reduced the response to $\mathrm{P}$ application and inoculation. The soybean response to inoculation was greater in cultivated soils and when the lower $P$ dose was applied. The soybean response magnitude to these variables was different among the studied Latosols. The mineralogical and chemical attributes of the Latosols were determinants.
\end{abstract}

Index terms: Mycorrhiza; Latosols (Oxisols); available P; long-term cultivation.

\begin{abstract}
RESUMO
O P é um nutriente chave no manejo da fertilidade de solos tropicais altamente intemperizados. Este trabalho foi conduzido com o objetivo de avaliar a influência da interação entre doses de $P$, inoculação micorrízica e histórico de uso do solo no crescimento da soja e absorção de $\mathrm{P}$ em cinco Latossolos com atributos físicos, químicos e mineralógicos contrastantes recebendo adubação fosfatada por longo período (> 15 anos). As plantas foram cultivadas em potes plásticos (4,5 L) contendo $4 \mathrm{~kg}$ de solo em um delineamento inteiramente casualizado,

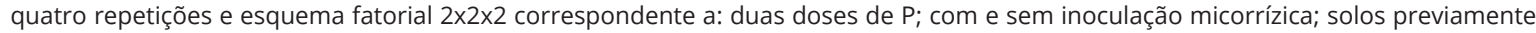
cultivados e não cultivados (sob vegetação nativa). Foram realizados dois cultivos de dez semanas cada. Após cada um dos cultivos, avaliaram-se a massa seca da parte aérea, concentração e acúmulo de $\mathrm{P}$ na parte aérea. $\mathrm{O}$ cultivo do solo reduziu a resposta à aplicação de $\mathrm{P}$ e inoculação. A resposta da soja à inoculação foi maior nos solos cultivados e quando a menor dose de $\mathrm{P}$ foi aplicada. A magnitude dessas respostas foi diferente entre os Latossolos estudados, sendo os atributos mineralógicos e químicos dos Latossolos determinantes.
\end{abstract}

Termos para indexação: Micorrizas; Latossolos; P disponível; cultivo do solo.

\section{INTRODUCTION}

In highly weathered tropical soils, such as Latosols (Oxisols), the nutrient phosphorus (P), beyond its natural deficiency in most cases (Lopes; Guilherme, 2016), have high adsorption by iron and aluminum oxides (Camargo et al., 2015; Rodrigues et al., 2016), making it less available to plants. The phosphate fertilization in the Brazilian Cerrado soils was one of the practices responsible for boosting agriculture in this biome (Lopes; Guilherme,
2016), where currently much of the agricultural and livestock farming in Brazil is concentrated, mainly soybean production. With a planted area of about 30 million hectares, there is an estimated soybean production of 96 million tons for the 2015/2016 harvest (47\% of total production of all grains grown in the country) (Companhia Nacional de Abastecimento - Conab, 2016). The continuous expansion of the soybean area in Brazil is related to the complete replacement of nitrogen fertilizer with biological $\mathrm{N}_{2}$ fixation (Salvagiotti et al., 2008) and 
by the best management practices in soil fertility (Lopes; Guilherme, 2016).

In soil fertility management, several practices have been proposed and adopted for increasing the availability of phosphorus in the soil. This increase has direct agronomic, environmental and economic implications. The symbiotic association between mycorrhizal fungi and plant roots increases the root surface area and the soil volume explored and consequently the nutrient uptake, especially P (Bressan et al., 2001; Rooney et al., 2011; Sharif and Claassen, 2011; Smith et al., 2011; Zhao et al., 2015). In addition to increasing $\mathrm{P}$ uptake, the symbiosis between roots and mycorrhizal fungi can make plants more resistant to water stress (Zarik et al., 2016), stimulate biological nitrogen fixation (Whabi et al., 2016), increase tolerance to heavy metals (Hritozkova et al., 2016), promote soil aggregation (Leifheit; Verbruggen; Rillig, 2015) and even mitigate adverse effects of soil pH (Moreira; Siqueira, 2006). Therefore, the mycorrhizal fungi play an important role in the integrated management of soil fertility (Cozzolino; Meo; Piccolo, 2013).

The physiological and biochemical mechanisms of mycorrizal infections are not fully understood (Ramos et al., 2011) and, consequently, various plant responses may occur (Hart; Forsythe, 2012), especially if one considers the diversity of chemical, physical, biological and mineralogical soil properties. In addition, the fertilizer application and soil land use affect the mycorrizal inoculation (Qin et al., 2015). The effects of P source on mycorrizal inoculation were found by Covacevich, Marino and Echeverría (2006). Also, the soil $P$ content affects the colonization and sporulation (Bressan et al., 2001; Covacevich; Echeverría; Aguirrezabal, 2007; Xie et al., 2014). The increased availability of soil P may lower mycorrhizal colonization (Covacevich; Echeverría; Aguirrezabal, 2007; Xu et al., 2014). Physiological and biochemical processes which self-regulate symbiosis seem to occur in plants well-nourished in P (Moreira; Siqueira, 2006).

Thus, the objective of this work was to evaluate soybean growth and $\mathrm{P}$ uptake influenced by phosphorus fertilization, with and without mycorrhizal inoculation in five Latosols (Oxisols) with contrasting chemical, physical and mineralogical properties cultivated for long periods (more than 15 years) and non-cultivated (under native vegetation).

\section{MATERIAL AND METHODS}

Five Latosols (Oxisols), cultivated for long periods and non-cultivated with contrasting chemical, physical and mineralogical properties were used for this study, being them dystrocohesive Yellow Latosol (LAx) developed from sediments of Barreiras Formation (Aracruz, Espírito Santo State), dystrophic Yellow Latosol (LAd) developed from alteration of gneiss (Lavras, Minas Gerais State), acric Red Latosol (LVw) developed from sediments of Tertiary (Uberlândia, Minas Gerais State), dystroferric Red Latosol (LVdfg) developed from gabbro (Lavras, Minas Gerais State), and dystroferric Red Latosol (LVdft) developed from tuffite (Patos de Minas, Minas Gerais State). LAx and LAd presented sand clay and clay loam texture, respectively; LVdft presented clayey texture, whereas LVw and LVdfg, very clayey texture. $\mathrm{LAd}$ and $\mathrm{LVW}$ have been cultivated with annual crops for more than 15 years and the native vegetation comprises semicaducifolious tropical forest. LAx has been cultivated with annual crops (beans and corn) for more than 15 years and soil was covered with Panicum maximum during the three years prior to the soil sampling. LVdfg has been cultivated with annual crops for over 15 years and in the five years prior to soil sampling, soil was covered with Brachiaria decumbens. On these two soils, native vegetation consists of semiperinnial tropical forest. LVdft, in turn, has been cultivated with annual crops for over 15 years and, in the five years prior to soil sampling, soil was covered with Brachiaria decumbens, while the native vegetation was semicaducifolious tropical forest. All the soils were under the same management practices, which were annual phosphate fertilization and liming occasionally. In each soil, composite samples were collected at a depth of $0-20 \mathrm{~cm}$ under both native vegetation (non-cultivated - NC) and agricultural use (cultivated - C) for physical, chemical and mineralogical characterization (Empresa Brasileira de Pesquisa Agropecuária - Embrapa, 2011).

The physical characterization involved the determination of clay, silt and sand content by the pipette method. The routine chemical characterization involved the determination of the following properties: $\mathrm{pH}$ in water (soil:water 1:2.5), P-Mehlich 1 and 3, P extracted by anionexchange resin (P resine), $\mathrm{Al}^{3+}, \mathrm{Ca}^{2+}, \mathrm{Mg}^{2+}, \mathrm{K}^{+}, \mathrm{H}+\mathrm{Al}$, soil organic carbon (SOC) and micronutrients $(\mathrm{B}, \mathrm{Cu}, \mathrm{Fe}, \mathrm{Mn}$ e $\mathrm{Zn}$ ). The chemical and mineralogical composition of the clay fraction was evaluated regarding the following methods: dithionite iron $\left(\mathrm{Fe}_{\mathrm{d}}\right)$ (Embrapa, 2011); oxalate iron $\left(\mathrm{Fe}_{\mathrm{o}}\right)$ (Schwertmann, 1964); $\mathrm{SiO}_{2}, \mathrm{Al}_{2} \mathrm{O}_{3}, \mathrm{Fe}_{2} \mathrm{O}_{3}, \mathrm{TiO}_{2}$ and $\mathrm{P}_{2} \mathrm{O}_{5}$ content after sulfuric acid digestion (Embrapa, 2011); hematite and goethite by X-ray diffraction after iron oxide concentration (Kämpf; Schwertmann, 1982); kaolinite and gibbsite by differential thermal analysis in iron-free samples (Embrapa, 2011). The maximum P adsorption capacity of each soil (MPAC) was also determined according to Olsen and Watanabe (1957), with details of the methodology described in Motta et al. (2002). Table 1 presents the physical, chemical and mineralogical properties of the selected Latosols. 
Table 1: Physical, chemical and mineralogical properties of Latosols used in the study before treatment application.

\begin{tabular}{|c|c|c|c|c|c|c|c|c|c|c|}
\hline \multirow{2}{*}{ Soil properties } & \multicolumn{2}{|c|}{ LAx } & \multicolumn{2}{|c|}{ LAd } & \multicolumn{2}{|c|}{ LVW } & \multicolumn{2}{|c|}{ LVdfg } & \multicolumn{2}{|c|}{ LVdft } \\
\hline & $\mathrm{NC}$ & C & NC & C & NC & C & NC & C & NC & C \\
\hline Clay $\left(\mathrm{g} \mathrm{kg}^{-1}\right)$ & 440 & 430 & 360 & 380 & 670 & 630 & 640 & 660 & 580 & 600 \\
\hline Silt $\left(\mathrm{g} \mathrm{kg}^{-1}\right)$ & 90 & 110 & 200 & 180 & 120 & 100 & 160 & 190 & 240 & 230 \\
\hline Sand $\left(\mathrm{g} \mathrm{kg}^{-1}\right)$ & 470 & 460 & 440 & 440 & 210 & 270 & 200 & 150 & 180 & 170 \\
\hline $\mathrm{pH}$ & 5.7 & 5.9 & 5.4 & 5.7 & 4.9 & 5.8 & 5.5 & 6.1 & 4.9 & 5.2 \\
\hline $\mathrm{Al}^{3+}\left(\mathrm{cmol}_{c} \mathrm{dm}^{-3}\right)$ & 0.0 & 0.0 & 0.6 & 0.0 & 0.9 & 0.0 & 0.0 & 0.0 & 0.8 & 0.2 \\
\hline $\mathrm{Ca}^{2+}\left(\mathrm{cmol}_{\mathrm{c}} \mathrm{dm}^{-3}\right)$ & 3.2 & 3.0 & 1.7 & 3.4 & 1.2 & 3.7 & 3.2 & 7.2 & 2.3 & 2.2 \\
\hline $\mathrm{Mg}^{2+}\left(\mathrm{cmol}_{\mathrm{c}} \mathrm{dm}^{-3}\right)$ & 0.8 & 1.2 & 0.8 & 0.9 & 0.1 & 0.2 & 0.2 & 0.3 & 0.9 & 1.1 \\
\hline $\mathrm{K}^{+}\left(\mathrm{mg} \mathrm{dm}^{-3}\right)$ & 90 & 73 & 101 & 72 & 36 & 59 & 153 & 162 & 64 & 166 \\
\hline $\mathrm{H}+\mathrm{Al}\left(\mathrm{cmol}_{\mathrm{c}} \mathrm{dm}^{-3}\right)$ & 4.0 & 2.3 & 6.3 & 3.6 & 9.8 & 2.9 & 4.0 & 2.3 & 12.3 & 7.0 \\
\hline P-Mehlich1 ( $\left.\mathrm{mg} \mathrm{dm}^{-3}\right)$ & 4 & 22 & 4 & 12 & 2 & 45 & 3 & 7 & 78 & 63 \\
\hline P-Resine ( $\mathrm{mg} \mathrm{dm}^{-3}$ ) & 11 & 23 & 10 & 27 & 7 & 48 & 17 & 18 & 91 & 57 \\
\hline$B\left(m g d m^{-3}\right)$ & 0.31 & 0.31 & 0.15 & 0.23 & 0.23 & 0.26 & 0.26 & 0.29 & 0.26 & 0.26 \\
\hline $\mathrm{Cu}\left(\mathrm{mg} \mathrm{dm}^{-3}\right)$ & 0.9 & 3.0 & 0.5 & 2.0 & 1.6 & 1.0 & 4.1 & 5.1 & 7.4 & 10.2 \\
\hline $\mathrm{Fe}\left(\mathrm{mg} \mathrm{dm}^{-3}\right)$ & 176 & 150 & 150 & 159 & 329 & 100 & 109 & 116 & 526 & 177 \\
\hline $\mathrm{Mn}\left(\mathrm{mg} \mathrm{dm^{-3 }}\right)$ & 66 & 57 & 27 & 75 & 19 & 6 & 94 & 21 & 114 & 78 \\
\hline $\mathrm{Zn}\left(\mathrm{mg} \mathrm{dm}^{-3}\right)$ & 2.5 & 5.7 & 1.3 & 7.9 & 1.4 & 2.8 & 2.7 & 8.3 & 2.6 & 4.7 \\
\hline $\mathrm{SB}\left(\mathrm{cmol}_{c} \mathrm{dm}^{-3}\right)$ & 4.2 & 4.4 & 2.8 & 4.7 & 1.4 & 4.1 & 3.8 & 7.9 & 3.4 & 3.7 \\
\hline $\mathrm{t}\left(\mathrm{cmol}_{\mathrm{c}} \mathrm{dm}^{-3}\right)$ & 4.2 & 4.4 & 2.9 & 4.7 & 2.3 & 4.1 & 3.8 & 7.9 & 4.2 & 3.9 \\
\hline $\mathrm{T}\left(\mathrm{cmol}_{\mathrm{c}} \mathrm{dm}^{-3}\right)$ & 8.2 & 6.7 & 9.1 & 8.3 & 11.2 & 7.0 & 7.8 & 10.2 & 15.7 & 10.7 \\
\hline V (\%) & 51 & 66 & 31 & 57 & 13 & 58 & 49 & 77 & 21 & 35 \\
\hline m (\%) & 0 & 0 & 18 & 0 & 39 & 0 & 0 & 0 & 19 & 5 \\
\hline $\mathrm{SOC}\left(\mathrm{g} \mathrm{kg}^{-1}\right)$ & 22.3 & 13.6 & 21.9 & 19.5 & 26.4 & 19.1 & 30.0 & 23.6 & 49.5 & 31.9 \\
\hline $\mathrm{SiO}_{2}{ }^{1 /}\left(\mathrm{g} \mathrm{kg}^{-1}\right)$ & 176 & 178 & 90 & 103 & 129 & 189 & 158 & 154 & 53 & 41 \\
\hline $\mathrm{Al}_{2} \mathrm{O}_{3}{ }^{1 /}\left(\mathrm{g} \mathrm{kg}^{-1}\right)$ & 172 & 182 & 141 & 174 & 268 & 323 & 279 & 271 & 239 & 226 \\
\hline $\mathrm{Fe}_{2} \mathrm{O}_{3}{ }^{1 /}\left(\mathrm{g} \mathrm{kg}^{-1}\right)$ & 11 & 19 & 31 & 51 & 106 & 123 & 220 & 177 & 326 & 379 \\
\hline $\mathrm{TiO}_{2}{ }^{1 /}\left(\mathrm{g} \mathrm{kg}^{-1}\right)$ & 12 & 12 & 8 & 11 & 20 & 23 & 27 & 31 & 74 & 89 \\
\hline $\mathrm{P}_{2} \mathrm{O}_{5}{ }^{1 /}\left(\mathrm{g} \mathrm{kg}^{-1}\right)$ & 0.07 & 0.07 & 0.12 & 0.23 & 0.34 & 0.46 & 0.49 & 0.68 & 8.30 & 10.37 \\
\hline $\mathrm{Fe}_{\mathrm{o}}\left(\mathrm{g} \mathrm{kg}^{-1}\right)$ & 0.3 & 0.7 & 1.9 & 1.8 & 2.4 & 2.1 & 2.9 & 2.8 & 5.3 & 5.1 \\
\hline $\mathrm{Fe}_{d}\left(\mathrm{~g} \mathrm{~kg}^{-1}\right)$ & 1 & 11 & 34 & 46 & 55 & 61 & 87 & 85 & 121 & 117 \\
\hline $\mathrm{Kt}\left(\mathrm{g} \mathrm{kg}^{-1}\right)$ & 260 & 230 & 110 & 100 & 230 & 190 & 240 & 230 & tr. & tr. \\
\hline $\mathrm{Gb}\left(\mathrm{g} \mathrm{kg}^{-1}\right)$ & 10 & 10 & 60 & 90 & 270 & 110 & 200 & 220 & 260 & 300 \\
\hline $\mathrm{Kt} /(\mathrm{Kt}+\mathrm{Gb})$ & 0.96 & 0.96 & 0.65 & 0.53 & 0.46 & 0.63 & 0.55 & 0.51 & 0.00 & 0.00 \\
\hline $\mathrm{Gt} /(\mathrm{Gt}+\mathrm{Hm})$ & 1.00 & 1.00 & 1.00 & 1.00 & 0.17 & 0.14 & 0.34 & 0.45 & 0.09 & 0.12 \\
\hline MPAC $\left(\mathrm{mg} \mathrm{kg}^{-1}\right)$ & 476 & 324 & 621 & 676 & 1,233 & 1,052 & 1,393 & 1,393 & 3,000 & 2,092 \\
\hline
\end{tabular}

$\mathrm{pH}$ : in water (soil/water ratio 1:2.5); SB: sum of bases; t: effective cation exchange capacity; T: potential cation exchange capacity

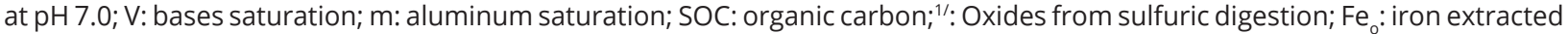
by ammonium oxalate; $\mathrm{Fe}_{\mathrm{d}}$ : iron extracted by sodium dithionite-citrate-bicarbonate; Kt: kaolinite; Gb: gibbsite; MPAC: maximum phosphorus adsorption capacity; NC: non-cultivated; C: cultivated; Micronutrients (Cu, Fe, Mn and Zn) in Mehlich-1 extractant solution; B by hot water method; SOC by Walkley \& Black method; tr.: trace concentration. 
For the cultivation of soybean (Glycine max (L.) Merrill), variety $\mathrm{CAC}-1$, an experiment was conducted using 4.5L-plastic pots (containing $4 \mathrm{~kg}$ of soil passed through $5 \mathrm{~mm}$ sieve) in a greenhouse, adopting a completely randomized design with four replications in a $2 \times 2 \times 2$ factorial scheme, as follows: i) factor $\mathrm{H}$ (use history): non-cultivated (native vegetation) (NC) and under cultivation for long periods (C); ii) factor P (P doses): P1 (lower dose) and P2 (higher dose); iii) factor I (mycorrhizal inoculation): no inoculation (NI) and inoculation (I).

For pot preparation, soil samples were liming aimed at raising base saturation to $60 \%$, using dolomitic limestone with a $\mathrm{Ca}: \mathrm{Mg}$ ratio of $4: 1$ and effective neutralizing value of $100 \%$. The soil remained incubated for 45 days while maintaining a moisture content equivalent to $60 \%$ of the total pore volume. Basic fertilization was carried out in order to reach the following soil nutrient contents $\left(\mathrm{mg} \mathrm{kg}^{-1}\right)$ : $\mathrm{K}(80) ; \mathrm{S}$ (35); B (0.8); Fe (3.0); Cu (1.5); Mn (3.6); Zn (5.0); and Mo (0.15). These levels were reached through adding nutrient solutions, one for the macronutrients and another for micronutrients. The following sources, p.a., were used: $\mathrm{NH}_{4} \mathrm{H}_{2} \mathrm{PO}_{4}, \mathrm{NH}_{4} \mathrm{NO}_{3}, \mathrm{~K}_{2} \mathrm{SO}_{4}, \mathrm{H}_{3} \mathrm{BO}_{3}$, $\mathrm{FeSO}_{4} \cdot 7 \mathrm{H}_{2} \mathrm{O}, \mathrm{CuSO}_{4} \cdot 5 \mathrm{H}_{2} \mathrm{O}, \mathrm{MnSO}_{4} \cdot \mathrm{H}_{2} \mathrm{O}, \mathrm{ZnSO}_{4} \cdot 7 \mathrm{H}_{2} \mathrm{O}$ and $\left(\mathrm{NH}_{4}\right)_{6} \mathrm{Mo}_{7} \mathrm{O}_{24} \cdot 4 \mathrm{H}_{2} \mathrm{O}$. By varying the composition of the nutrient solutions, the above soil contents were obtained. Sufficiency of $\mathrm{Ca}$ and $\mathrm{Mg}$ were supplied via liming.

The $\mathrm{P}$ doses applied in each soil were based on the maximum phosphorus dose required for maximum corn dry mass production, obtained in a preliminary assay under greenhouse conditions. Table 2 shows the $\mathrm{P}$ doses used for each situation. The higher dose (P2) corresponds to $50 \%$ of the dose required for maximum output, and the lower dose (P1) corresponds to $5 \%$. These doses were established in order to not inhibit mycorrhizae development (Paula; Siqueira, 1987), in the case of the highest dose, and a minimum quantity to not limit plant growth in the lowest dose.

After application of $\mathrm{P}$ doses and incubation, fumigation of the soil material was done with methyl bromide. After a ventilation period, mycorrhizal inoculation was performed in half of the soil pots, by the application of a $1 \mathrm{~mL}$ suspension containing spores of the mycorrhizal fungus Glomus etunicatum, prepared by the method of Gerdermann and Nicolson (1963). Approximately 300 spores were applied per pot in holes in the soil, which were also used for placement of the seeds. Four seeds were used and later reduced to two plants per pot by thinning. The soybean seeds were previously inoculated with Bradyrhizobium japonicum. After planting, the partial recovery of the microbiota in all pots was conducted via inoculation with filtered extract prepared from the soil itself under conditions prior to fumigation.

Table 2: $\mathrm{P}$ doses used in the study ( $\mathrm{P} 1$ and $\mathrm{P} 2$ ) as a function of the maximum dose for corn dry mass production - preliminary test.

\begin{tabular}{cccc}
\hline Soil & $\begin{array}{c}\text { Dose for maximum } \\
\text { production } \\
\left(\mathrm{mg} \mathrm{kg}^{-1}\right)\end{array}$ & $\begin{array}{c}\mathrm{P} 1 \\
\left(\mathrm{mg} \mathrm{kg}^{-1}\right)\end{array}$ & $\begin{array}{c}\mathrm{P} 2 \\
\left(\mathrm{mg} \mathrm{kg}^{-1}\right)\end{array}$ \\
\hline LAx-NC & 270 & 15 & 150 \\
LAx-C & 312 & 15 & 150 \\
LAd-NC & 295 & 15 & 150 \\
LAd-C & 282 & 15 & 150 \\
LVw-NC & $\geq 400$ & 20 & 200 \\
LVw-C & $\geq 400$ & 20 & 200 \\
LVdfg-NC & 263 & 15 & 150 \\
LVdfg-C & 449 & 15 & 150 \\
LVdft-NC & 575 & 30 & 300 \\
LVdft-C & 402 & 30 & 300 \\
\hline NC:
\end{tabular}

NC: non-cultivated; C: cultivated.

The experiment comprised two cultivations, maintaining the soil moisture at $60 \%$ of the total pore volume. After the first cultivation of 10 weeks duration (development stage R1/R2 - flowering), the plants were cut close to the ground, washed and dried in an forced air circulation oven for 72 hours at $60{ }^{\circ} \mathrm{C}$. The roots also were removed to evaluate mycorrhizal colonization (Giovannetti; Mosse, 1980). Soil sampling for chemical characterization (as previously described) was also carried out.

Potassium and sulfur were replaced in the soil material remaining from the first cultivation, by applying $80 \mathrm{mg} \mathrm{kg}^{-1}$ of $\mathrm{K}_{2} \mathrm{SO}_{4}$, then again planting and growing the second cultivation, which was also terminated at 10 weeks. As in the first cultivation, the shoot was sampled to obtain the dry mass and $\mathrm{P}$ content, roots to evaluate mycorrhizal colonization and soil for chemical characterization. The $\mathrm{P}$ content in shoot dry mass was determined by colorimetric molybdenum blue method (Embrapa, 2009). Accumulated P was calculated by: $\mathrm{P}$ content $\left(\mathrm{mg} \mathrm{kg}^{-1}\right)$ x shoot dry mass $(\mathrm{kg})$.

Variance analysis and Tukey test was performed in order to assess the statistical differences $(p<0.05)$ of the effects of interaction between $\mathrm{P}$ doses, mycorrhizal 
inoculation and non-inoculation, and historical land use (cultivated or non-cultivated soils) on soybean shoot dry mass, $\mathrm{P}$ concentration in shoot dry mass and total accumulated $\mathrm{P}\left(1^{\text {st }}+2^{\text {nd }}\right.$ cultivation $)$.

\section{RESULTS AND DISCUSSION}

\section{Shoot dry mass (SDM)}

For the first cultivation, in all soils, greater SDM was found with the highest $\mathrm{P}$ dose (P2) in non-cultivated soils (NC). In the absence of inoculation, the response was greater in LAx and LVdft, as can been seen for LAx, where was an increase in SDM from 10.71 to $32.07 \mathrm{~g}$
$(+200 \%)$ in the absence of inoculation, and from 20.05 to $30.68 \mathrm{~g}(+53 \%)$ in its presence (Table 3$)$. For the second cultivation, the highest SDM was obtained with the P2 dose in the NC LAx and LVdft, the P2 dose in the LVw and $\mathrm{P} 2$ dose in inoculated LAd and LVdfg. The response to increasing $\mathrm{P}$ content in the soil varied considerably among soils, reflecting the difference in their chemical, physical and mineralogical properties (Motta et al. 2002). The greater response in the $\mathrm{NC}$ is due to lesser available soil P content (Table 4), which limited plant development. In the presence of inoculation, the responses were low and there were no differences in relation to the land use history in LAx. The LVdft soil showed a lower response to $\mathrm{P}$, being lower in the non-cultivated soil.

Table 3: Soybean shoot dry mass influenced by the interaction between historical land use (NC: non-cultivated; C: cultivated for long periods), P doses (P1 and P2) and mychorrizal inoculation (NI: non-inoculated; I: inoculated) in five Latosols (Oxisols).

\begin{tabular}{|c|c|c|c|c|c|c|c|c|}
\hline \multirow{3}{*}{ Treat. } & \multicolumn{4}{|c|}{$1^{\text {st }}$ cultivation (double interaction) } & \multicolumn{4}{|c|}{$2^{\text {nd }}$ cultivation (double interaction) } \\
\hline & \multicolumn{2}{|c|}{$\mathrm{P}$ doses } & \multicolumn{2}{|c|}{ Inoculation } & \multicolumn{2}{|c|}{ P doses } & \multicolumn{2}{|c|}{ Inoculation } \\
\hline & P1 & P2 & $\mathrm{NI}$ & 1 & P1 & P2 & $\mathrm{NI}$ & 1 \\
\hline & & '---------- & ------------- & ------------L/ & ------------. & 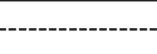 & ----------- & \\
\hline $\mathrm{NC}$ & 7.97 bB & $20.61 \mathrm{aA}$ & $12.00 \mathrm{aB}$ & $16.58 \mathrm{bA}$ & $2.94 \mathrm{bB}$ & $15.73 \mathrm{aA}$ & $8.60 \mathrm{aB}$ & $10.07 \mathrm{bA}$ \\
\hline C & $12.77 \mathrm{aB}$ & $17.52 \mathrm{bA}$ & $11.69 \mathrm{aB}$ & $18.61 \mathrm{aA}$ & $6.93 \mathrm{aB}$ & $14.45 \mathrm{bA}$ & $9.29 \mathrm{aB}$ & $12.01 \mathrm{aA}$ \\
\hline $\mathrm{P} 1$ & -- & -- & $5.48 \mathrm{bB}$ & $15.26 \mathrm{bA}$ & -- & -- & 4.07 bB & $5.71 \mathrm{bA}$ \\
\hline $\mathrm{P} 2$ & -- & -- & $18.22 \mathrm{aB}$ & $19.52 \mathrm{aA}$ & -- & -- & $13.81 \mathrm{aB}$ & $16.37 \mathrm{aA}$ \\
\hline $\mathrm{NC}$ & 7.23 bB & $23.32 \mathrm{aA}$ & $12.38 \mathrm{bB}$ & $18.17 \mathrm{aA}$ & 2.32 bB & $14.12 \mathrm{aA}$ & $7.61 \mathrm{bA}$ & $8.83 \mathrm{bA}$ \\
\hline C & $12.59 \mathrm{aB}$ & $21.17 \mathrm{bA}$ & $17.60 \mathrm{aA}$ & $16.17 \mathrm{bA}$ & $8.40 \mathrm{aB}$ & $15.78 \mathrm{aA}$ & $11.87 \mathrm{aA}$ & $12.31 \mathrm{aA}$ \\
\hline $\mathrm{P} 1$ & -- & -- & 8.08 bB & $11.74 \mathrm{bA}$ & -- & -- & $4.74 \mathrm{bA}$ & $5.98 \mathrm{bA}$ \\
\hline $\mathrm{P} 2$ & -- & -- & $21.90 \mathrm{aA}$ & $22.59 \mathrm{aA}$ & -- & -- & $14.74 \mathrm{aA}$ & $15.16 \mathrm{aA}$ \\
\hline $\mathrm{NC}$ & $6.56 \mathrm{aB}$ & $19.88 \mathrm{aA}$ & $9.69 \mathrm{aB}$ & $16.75 \mathrm{aA}$ & $4.91 \mathrm{aB}$ & $14.05 \mathrm{aA}$ & 6.33 bB & $12.62 \mathrm{aA}$ \\
\hline C & $5.61 \mathrm{aB}$ & $15.16 \mathrm{bA}$ & $9.58 \mathrm{aB}$ & $11.19 \mathrm{bA}$ & $4.07 \mathrm{aB}$ & $12.98 \mathrm{bA}$ & $8.32 \mathrm{aA}$ & $8.73 \mathrm{bA}$ \\
\hline P1 & -- & -- & 3.62 bB & $8.55 \mathrm{bA}$ & -- & -- & $2.88 \mathrm{bB}$ & $6.10 \mathrm{bA}$ \\
\hline P2 & -- & -- & $15.65 \mathrm{aB}$ & $19.39 \mathrm{aA}$ & -- & -- & $11.77 \mathrm{aB}$ & $15.25 \mathrm{aA}$ \\
\hline
\end{tabular}


Table 3: Continuation.

\begin{tabular}{|c|c|c|c|c|c|c|c|c|}
\hline \multirow{3}{*}{ Treat. } & \multicolumn{4}{|c|}{$1^{\text {st }}$ cultivation (double interaction) } & \multicolumn{4}{|c|}{$2^{\text {nd }}$ cultivation (double interaction) } \\
\hline & \multicolumn{2}{|c|}{$\mathrm{P}$ doses } & \multicolumn{2}{|c|}{ Inoculation } & \multicolumn{2}{|c|}{ P doses } & \multicolumn{2}{|c|}{ Inoculation } \\
\hline & P1 & P2 & $\mathrm{NI}$ & 1 & $\mathrm{P} 1$ & $\mathrm{P} 2$ & $\mathrm{NI}$ & I \\
\hline & \multicolumn{4}{|c|}{ Triple interaction } & & & & \\
\hline & \multicolumn{2}{|c|}{ P1 } & \multicolumn{2}{|c|}{ P2 } & & & & \\
\hline & $\mathrm{NI}$ & I & $\mathrm{NI}$ & I & & & & \\
\hline NC & $15.70 \mathrm{bBx}$ & $25.86 \mathrm{aBx}$ & $28.87 \mathrm{aAx}$ & $31.41 \mathrm{aAx}$ & $16.16 \mathrm{aB}$ & $21.12 \mathrm{aA}$ & $16.61 \mathrm{aB}$ & $20.67 \mathrm{aA}$ \\
\hline C & $10.76 \mathrm{aBx}$ & 19.09 aBy & $25.30 \mathrm{aAx}$ & 28.70aAx & $12.20 \mathrm{bB}$ & $18.58 \mathrm{bA}$ & $14.34 \mathrm{aA}$ & $16.44 \mathrm{bA}$ \\
\hline P1 & -- & -- & -- & -- & -- & -- & 11.47 bB & $16.90 \mathrm{bA}$ \\
\hline P2 & -- & -- & -- & -- & -- & -- & $19.49 \mathrm{aA}$ & $20.21 \mathrm{aA}$ \\
\hline NC & 10.71 bBy & $20.05 a B x$ & $32.07 \mathrm{aAx}$ & $30.68 \mathrm{aAx}$ & 8.49 bB & $20.28 \mathrm{aA}$ & $13.34 \mathrm{aB}$ & $15.43 \mathrm{aA}$ \\
\hline C & $18.26 \mathrm{aBx}$ & 14.81 bBy & $23.50 \mathrm{aAy}$ & 22.02aAy & $11.67 \mathrm{aB}$ & 17.59 bA & $14.34 \mathrm{aA}$ & $14.92 \mathrm{aA}$ \\
\hline P1 & -- & -- & -- & -- & -- & -- & $9.07 \mathrm{bB}$ & $11.08 \mathrm{bA}$ \\
\hline P2 & -- & -- & -- & -- & -- & -- & $18.60 \mathrm{aB}$ & $19.26 \mathrm{aA}$ \\
\hline
\end{tabular}

Double interaction, A and B compare the mean values horizontally, and a and b, compare them vertically. In triple interaction, $\mathrm{A}$ and $\mathrm{B}$ compare the effect of $\mathrm{P}$ dose (horizontally, within the same historical land use and inoculation procedure), $\mathrm{a}$ and $\mathrm{b}$ compare the inoculation effect (horizontally, within the same P dose and historical land use, and $x$ and y compare the historical land use effect (vertically, within the same $\mathrm{P}$ dose and inoculation procedure). Means followed by the same letters do not differ statistically by Tukey test at $5 \%$ probability.

Table 4: $P$ content in soils prior to the first soybean cultivation and after $1^{\text {st }}$ and $2^{\text {nd }}$ soybean cultivations.

\begin{tabular}{|c|c|c|c|c|c|c|c|c|c|}
\hline \multirow{2}{*}{$\mathrm{H} / \mathrm{P} / \mathrm{I}$} & \multicolumn{3}{|c|}{ Prior to $1^{\text {st }}$ cropping } & \multicolumn{3}{|c|}{ After $1^{\text {st }}$ cropping } & \multicolumn{3}{|c|}{ After $2^{\text {nd }}$ cropping } \\
\hline & M-1 & $M-3$ & Resine & M-1 & $M-3$ & Resine & M-1 & $M-3$ & Resine \\
\hline \multicolumn{10}{|c|}{ LAx } \\
\hline NC P2 I & --- & --- & --- & 61 & 75 & 53 & 47 & 69 & 37 \\
\hline $\mathrm{NCP} 2 \mathrm{NI}$ & 81 & 119 & 80 & 63 & 84 & 54 & 47 & 70 & 38 \\
\hline NC P1 I & --- & --- & --- & 10 & 13 & 7 & 6 & 12 & 6 \\
\hline $\mathrm{NCP} 1 \mathrm{NI}$ & 11 & 16 & 16 & 10 & 14 & 8 & 7 & 15 & 7 \\
\hline C P2 I & --- & --- & --- & 79 & 101 & 48 & 57 & 88 & 53 \\
\hline $\mathrm{CP} 2 \mathrm{NI}$ & 111 & 157 & 97 & 80 & 96 & 49 & 61 & 84 & 56 \\
\hline C P1 I & --- & --- & --- & 25 & 28 & 24 & 17 & 25 & 18 \\
\hline $\mathrm{CP} 1 \mathrm{NI}$ & 29 & 40 & 33 & 27 & 28 & 23 & 21 & 27 & 18 \\
\hline \multicolumn{10}{|c|}{ LAd } \\
\hline NC P2 I & --- & --- & --- & 32 & 44 & 46 & 20 & 46 & 30 \\
\hline NC P2 NI & 42 & 64 & 63 & 30 & 43 & 53 & 23 & 46 & 33 \\
\hline NC P1 I & --- & --- & --- & 5 & 8 & 10 & 4 & 7 & 8 \\
\hline
\end{tabular}


Table 4: Continuation.

\begin{tabular}{|c|c|c|c|c|c|c|c|c|c|}
\hline \multirow{2}{*}{$\mathrm{H} / \mathrm{P} / \mathrm{I}$} & \multicolumn{3}{|c|}{ Prior to $1^{\text {st }}$ cropping } & \multicolumn{3}{|c|}{ After $1^{\text {st }}$ cropping } & \multicolumn{3}{|c|}{ After $2^{\text {nd }}$ cropping } \\
\hline & M-1 & M-3 & Resine & M-1 & M-3 & Resine & M-1 & M-3 & Resine \\
\hline $\mathrm{NCP} 1 \mathrm{NI}$ & 5 & 10 & 14 & 5 & 9 & 12 & 4 & 8 & 9 \\
\hline C P2 I & --- & --- & --- & 34 & 48 & 60 & 25 & 42 & 47 \\
\hline C P2 NI & 41 & 58 & 82 & 28 & 38 & 52 & 21 & 39 & 40 \\
\hline CP1 I & --- & --- & --- & 13 & 14 & 21 & 10 & 14 & 18 \\
\hline C P1 NI & 14 & 16 & 80 & 12 & 16 & 22 & 10 & 15 & 20 \\
\hline \multicolumn{10}{|c|}{ LVw } \\
\hline NC P2 I & --- & --- & --- & 22 & 39 & 51 & 14 & 31 & 36 \\
\hline NC P2 NI & 32 & 53 & 84 & 26 & 49 & 58 & 16 & 38 & 40 \\
\hline NC P1 I & --- & --- & --- & 3 & 7 & 10 & 2 & 5 & 10 \\
\hline NC P1 NI & 3 & 6 & 14 & 3 & 7 & 11 & 2 & 5 & 8 \\
\hline C P2I & --- & --- & --- & 92 & 78 & 80 & 79 & 64 & 89 \\
\hline C P2 NI & 109 & 75 & 114 & 92 & 79 & 78 & 80 & 62 & 90 \\
\hline CP1 I & --- & --- & --- & 55 & 25 & 49 & 48 & 23 & 41 \\
\hline C P1 NI & 54 & 25 & 63 & 56 & 24 & 54 & 52 & 24 & 42 \\
\hline \multicolumn{10}{|c|}{ LVdfg } \\
\hline NC P2 I & --- & --- & --- & 13 & 21 & 57 & 9 & 16 & 37 \\
\hline NC P2 NI & 21 & 30 & 82 & 15 & 24 & 63 & 11 & 21 & 43 \\
\hline NC P1 I & --- & --- & --- & 4 & 7 & 15 & 3 & 5 & 13 \\
\hline NC P1 NI & 4 & 5 & 23 & 5 & 6 & 16 & 3 & 5 & 13 \\
\hline C P2 I & --- & --- & --- & 22 & 33 & 53 & 17 & 32 & 37 \\
\hline C P2 NI & 31 & 42 & 81 & 24 & 32 & 56 & 19 & 34 & 40 \\
\hline C P1 I & --- & --- & --- & 8 & 16 & 19 & 8 & 13 & 15 \\
\hline C P1 NI & 11 & 13 & 25 & 9 & 16 & 20 & 9 & 13 & 17 \\
\hline \multicolumn{10}{|c|}{ LVdft } \\
\hline NC P2 I & --- & --- & --- & 118 & 107 & 92 & 107 & 67 & 128 \\
\hline NC P2 NI & 128 & 102 & 146 & 123 & 114 & 104 & 95 & 69 & 126 \\
\hline NC P1 I & --- & --- & --- & 82 & 84 & 75 & 64 & 50 & 82 \\
\hline $\mathrm{NC}$ P1 NI & 80 & 62 & 121 & 79 & 74 & 82 & 67 & 75 & 78 \\
\hline C P2 I & -- & --- & --- & 120 & 97 & 111 & 95 & 98 & 135 \\
\hline C P2 NI & 123 & 88 & 178 & 121 & 97 & 134 & 98 & 98 & 136 \\
\hline CP1 I & --- & --- & --- & 67 & 55 & 101 & 59 & 61 & 65 \\
\hline C P1 NI & 71 & 45 & 109 & 71 & 60 & 99 & 58 & 67 & 90 \\
\hline
\end{tabular}

H: Historical land use (NC - non-cultivated, C - cultivated); P: doses of P (P2 - higher dose, P1 - lower dose); I: mychorrizal inoculation (I - inoculated, NI - non-inoculated); M-1 e M-3: P extracted by Mehlich-1 e Mehlich-3, respectively; Resine: P extracted by anionic exchange resin method.

Due to increased $\mathrm{P}$ uptake capacity by the soybean roots associated with mycorrhizae and, therefore, the greater use of this P (Paula; Siqueira,
1987; Bressan et al., 2001), the inoculation reduced the response to the $\mathrm{P}$ doses. For plants grown in LAd, for example, the SDM increased from $5.48 \mathrm{~g}$ to 18.22 
$\mathrm{g}$ in the absence of inoculation, whereas in its presence, SDM increased from $15.26 \mathrm{~g}$ to $19.52 \mathrm{~g}$ (Table 3). The smaller increase in the presence of inoculation occurred because SDM reached $15.26 \mathrm{~g}$, even with the lowest $\mathrm{P}$ dose (P1) due to the effect of the mycorrhizal fungi on $\mathrm{P}$ uptake. In LAd, LVw and LVdfg, the response to P dose increased but was similar, being greater in $\mathrm{NC}$ than in cultivated soil (C) and in non-inoculated (NI) than in the inoculated (I), as can be seen for plants grown in LAd, in which this factor increased the SDM from 7.97 to $20.61 \mathrm{~g}(+158 \%)$ in the $\mathrm{NC}$ and from 12.77 to $17.52 \mathrm{~g}(38 \%)$ in the $\mathrm{C}$. The greater response in the $\mathrm{NC}$ was due to the low P content $\left(5 \mathrm{mg} \mathrm{dm}^{-3}\right)$ (Table 4). In the LVdfg, the differences between $\mathrm{NC}$ and $\mathrm{C}$ were very small compared to the other soils.

In the second cultivation (Table 3 ), the response in LAx and LAd was greater in the non-cultivated soil than in the cultivated soil, and for LVdfg and LVdft, higher in the cultivated than in the NC. In all soils, the responses were greater in the absence of inoculation than in its presence, which indicates the effect of mycorrhizae in reducing the need for applied P. Mycorrhizal inoculation with Asparagus officinallis $\mathrm{L}$. decreased the $\mathrm{P}$ content in the soil necessary for the maximum shoot dry mass production (Xu et al., 2014). Thus, as in the first cultivation, the lesser responses to the elevated $\mathrm{P}$ doses also occurred for the LVdft. The response to increased P dose was more pronounced in the second cultivation due to the low SDM production in soils that received the lower P dose (P1), which was observed for LAd, LVw and LVdfg. In the LAd, the increase in P level increased the SDM from $7.97 \mathrm{~g}$ to $20.61 \mathrm{~g}$ in the $\mathrm{NC}$ and from $12.77 \mathrm{~g}$ to $17.52 \mathrm{~g}$ in the $\mathrm{C}$, in the first cultivation (Table 3 ), corresponding to a $158 \%$ and $37 \%$ increase, whereas, in the second cultivation, the SDM went from $2.94 \mathrm{~g}$ to $15.73 \mathrm{~g}(+435 \%)$ in the $\mathrm{NC}$ and from $6.83 \mathrm{~g}$ to $14.45 \mathrm{~g}(+112 \%)$ at the C.

The response to $\mathrm{P}$ in the second cultivation was greater in I soils in relation to the NI (Table 3), but the difference between cultivation $\left(1^{\text {st }}\right.$ or $\left.2^{\text {nd }}\right)$ was reduced from the most kaolinitic to the most oxidic soils. The soils kaolinitic in character $(\mathrm{Ct} / \mathrm{Ct}+\mathrm{Gb})$ decreases in the order: $\mathrm{LAx}>\mathrm{LAd}>\mathrm{LVw}=\mathrm{LVdfg}>\mathrm{LVdft}$ (Table 1). In the first cultivation, the response increased by over $500 \%$ in relation to the second cultivation, while in the second, it increased only $18 \%$, which means that the LVdft, because of its higher total P content, and due to the more oxidic mineralogy, kept the SDM production more constant between the two cultivations.

In the first cultivation, the inoculation increased SDM in all soils, cultivation conditions, and $\mathrm{P}$ doses, except in cultivated $\mathrm{LVw}$ and the $\mathrm{LVw}$ that received the highest P dose (P2) (Table 3). The magnitude of its effects varied among the soils. In LAd inoculation increased the SDM from 12.00 to $16.58 \mathrm{~g} \mathrm{(38 \% )}$ in the $\mathrm{NC}$ and from 11.69 to $18.61 \mathrm{~g}(+59 \%)$ in C, while in the LVw these increases were $47 \%$ in the $\mathrm{NC}$ and there was no effect in the $\mathrm{C}$. The effect of inoculation was greater with $\mathrm{P} 1$, as is the case for plants grown in LAd, the first cultivation, where the SDM increased from 5.48 to $15.26 \mathrm{~g}(+178 \%)$ at P1, whereas, with P2 it went from 18.22 to $19.52 \mathrm{~g}$ (7\%). The interaction between the P content in soil and mycorrhization is also evident here. With the application of the lowest P dose (P1), the levels of this nutrient in the soil reached lower values (Table 4), 5 and $14 \mathrm{mg} \mathrm{dm}^{-3}$ in the $\mathrm{NC}$ and $\mathrm{C}$, respectively, favoring a colonization of 56 to $49 \%$ (Table 5) and increased plant development. With increasing $\mathrm{P}$ content in soil there was lesser colonization, 35 and $24 \%$ in $\mathrm{NC}$ and $\mathrm{C}$, and less effect on the SDM. In a study with wheat, it was found that the increase in $\mathrm{P}$ content in soil by $1 \mathrm{mg} \mathrm{kg}^{-1}$ decreased mycorrhizal colonization by $2.6 \%$ (Covacevich; Echeverría; Aguirrezabal, 2007). In soybean cultivation, the maximum mycorrhizal colonization occurred when applying doses between 15 and $30 \mathrm{mg} \mathrm{kg}^{-1}$ of $\mathrm{P}_{2} \mathrm{O}_{5}$ (Paula; Siqueira, 1987).

As a function of the phosphate fertilization during the previous long-term growing period, there was a greater $P$ availability in the cultivated soil and the response to the current application was lesser, resulting in increases of $49 \%$ and $29 \%$ in the presence and absence of inoculation, respectively. In P1, inoculation increased SDM from 10.71 to $20.05 \mathrm{~g} \mathrm{(+88 \% )} \mathrm{in} \mathrm{NC} \mathrm{LAx} \mathrm{and} \mathrm{caused} \mathrm{a} 20 \%$ reduction in the $\mathrm{C}$ (Table 3). When P2 was applied, there was no response to inoculation.

The inhibitory effect of inoculation on SDM grown in LAx at the lower P dose (P1) is due to phosphorus content in the soil $\left(28 \mathrm{mg} \mathrm{dm}^{-3}\right)$ (Table 4$)$ not being high enough to inhibit the development of fungus, with $50 \%$ colonization (Table 5) observed, but being above the content at which the fungus would have a positive effect on the soybean development. The fungus, in this case, may have behaved like a photosynthate drain according to Fitter (1991), hindering the development of the plant. Bressan et al. (2001) found that the soybean shoot dry mass increased linearly with $\mathrm{P}$ doses, independent of inoculation. For wheat, a soil P content of $15 \mathrm{mg} \mathrm{kg}^{-1}$ provided greater shoot dry mass production in the presence of inoculation, without, however, affecting colonization (Covacevich; Echeverría; Aguirrezabal, 2007). 
Table 5: Mychorrizal colonization in soybean (\%) in the studied soils as a function of historical land use and $P$ doses in the two cultivations.

\begin{tabular}{ccccc}
\hline Soil & $\begin{array}{c}\text { Historical } \\
\text { land use }\end{array}$ & P dose & $\begin{array}{c}1^{\text {st }} \\
\text { cultivation }\end{array}$ & $\begin{array}{c}2^{\text {nd }} \\
\text { cultivation }\end{array}$ \\
\hline LAx & NC & P1 & 34 & 17 \\
LAx & NC & P2 & 46 & 29 \\
LAx & C & P1 & 0 & 0 \\
LAx & C & P2 & 50 & 20 \\
LAd & NC & P1 & 35 & 26 \\
LAd & NC & P2 & 56 & 3 \\
LAd & C & P1 & 24 & 20 \\
LAd & C & P2 & 49 & 20 \\
LVw & NC & P1 & 65 & 33 \\
LVw & NC & P2 & 51 & 3 \\
LVw & C & P1 & 10 & 14 \\
LVw & C & P2 & 30 & 16 \\
LVdfg & NC & P1 & 56 & 38 \\
LVdfg & NC & P2 & 39 & 9 \\
LVdfg & C & P1 & 54 & 21 \\
LVdfg & C & P2 & 62 & 7 \\
LVdft & NC & P1 & 47 & 53 \\
LVdft & NC & P2 & 65 & 36 \\
LVdft & C & P1 & 36 & 28 \\
LVdft & C & P2 & 53 & 29 \\
\hline NC: non-CuVa &
\end{tabular}

NC: non-cultivated; C: cultivated; P: doses of P (P2 - higher dose, P1 - lower dose).

With the increased P dose, in the LAx the content of this nutrient reached 81 and $111 \mathrm{mg} \mathrm{dm}^{-3}$ (Table 4) in the NC and $\mathrm{C}$, respectively. For the $\mathrm{C}$, there was no colonization and for the NC, while $34 \%$ colonization was detected (Table 5), response to inoculation was not significant (Table 3). Under high soil P content and well-nourished plant conditions, a symbiosis self-regulation mechanism occurs (Moreira; Siqueira, 2006). In the LVdft-NC (Table 3) there was no response to inoculation in $\mathrm{P} 2$ due to the high $\mathrm{P}$ content in the soil (128 $\mathrm{mg} \mathrm{dm}^{-3}$ ) (Table 3), which, however, did not prevent a $47 \%$ colonization (Table 4 ). At the lower P dose (P1), there was $65 \%$ colonization and SDM increased from $15.70 \mathrm{~g}$ to $25.86 \mathrm{~g}(65 \%)$, despite the high soil $\mathrm{P}$ content $\left(82 \mathrm{mg} \mathrm{dm}^{-3}\right)$. In the cultivated LVdft, the soil $\mathrm{P}$ content, with $\mathrm{P} 1$ and $\mathrm{P} 2$, were 71 and $120 \mathrm{mg} \mathrm{dm}^{-3}$, and even with 53 and $36 \%$ colonization, there was no response to inoculation (Table 3).
In the second cultivation (Table 3), inoculation increased soybean SDM in NC LAx, LVdfg and LVdft. In $\mathrm{LVw}$, there was no response to inoculation regardless of land use history. Although there was colonization in the noncultivated soils as well as in the cultivated, except for the cultivated LAx (Table 4), where there was no colonization due to higher P levels (Table 3), and there was no increase in SDM due to mycorrhizal colonization. In LVw and LVdft, there was no response to inoculation, whereas in LVdfg there was a similar response as in the first cultivation, i.e. there was an SDM increase at both P doses, this increase being greater, however, with the lower P dose. In LAd, in the first cultivation, there was also no response at the greater P dose, while in the second cultivation there was a $19 \%$ increase (Table 3). In the LVw, although there was response at the lower P dose in the first cultivation, this did not occur in the second. In the other soils, the response to inoculation in the absence of $\mathrm{P}$ was lesser in the second cultivation. The lowest response at the lower P dose (Table 3 ) is due to the reduction of the content of the nutrient in the soil by the first cultivation, which also reduced the effect of the mycorrhizal fungi. When comparing the SDM production in noncultivated LAd and LVdf with the lowest P (7.97 and 6.56 $\mathrm{g}$ in the first cultivation and 2.94 and $4.91 \mathrm{~g}$ in the second), it was observed that although there was little difference between them in the first cultivation, the SDM reduction in the second cultivation (63 and 25\%) was lesser in the LVdfg. Since the values of available P (Mehlich-1) of these soils were equal, around $5 \mathrm{mg} \mathrm{dm}^{-3}$, it is concluded that the LVdfg has a greater ability to maintain production due to its greater total $\mathrm{P}$ content. This is possibly because of its more oxidic make up. The same was observed when comparing the production of SDM in response to the lower P dose and to inoculation, the reduction in the second cultivation was $63 \%$ and $29 \%$ in LVd and LVdfg, respectively. The comparison for cultivated soils was limited by the large difference among the soil $\mathrm{P}$ contents.

In summary, some situations were identified regarding the effect of inoculation on the SDM: i) where $\mathrm{P}$ contents in the soil were low, colonization occurred in the inoculated soil and there was a beneficial effect of inoculation on plant development; (ii) where P content in the soil was sufficient for normal plant development, there was colonization, but the fungus behaved more as a parasite, not contributing to the host plant nutrition and even harming normal development; (iii) soil where $\mathrm{P}$ was high, there was colonization, but no effect of mycorrhizae on plant development.; and (iv) where the P content was very high, there was no colonization and, therefore, no response to inoculation. 


\section{Phosphorus in the soybean shoot dry mass}

In the first cultivation, the greatest concentration of $\mathrm{P}$ in the soybean shoot dry mass occurred with the inoculation in LVdft (Table 6); with the higher P application in the LAx cultivated soil; with the inoculation and application of the lower P dose in inoculated and cultivated LAd, and the application of the higher P dose in $\mathrm{LVw}$ and LVdfg. The lowest values occurred in the lower $\mathrm{P}$ application in LAx; in non-inoculated LAd and LVdft soils and in non-inoculated and non-cultivated LVw and LVdfg soils.

In the second cultivation (Table 6), the highest shoot $P$ values were reached with inoculation and application of the higher P dose in cultivated LAd; with the higher P dose in non-cultivated and cultivated LAx and LVw soil; with the higher P dose in LVdfg, and application of the higher $\mathrm{P}$ dose and inoculation in LVdft soil. While the lowest $P$ values occurred with inoculation and the application of the lower P dose in non-cultivated LAd; with P1 and non-cultivated LAx; with P1 in non-inoculated LVdfg and LVdft soil and with P1 in LVw.

In the first cultivation, the increased $\mathrm{P}$ dose increased $\mathrm{P}$ concentration in the soybean shoot in all soils, except in cultivated LAd and inoculated LVdfg, and the magnitude of the response varied with the historical land use and inoculation. In LAx, the P increased from 0.79 to $1.41 \mathrm{~g} \mathrm{~kg}^{-1}(+78 \%)$ in the $\mathrm{NC}$ and from 1.06 to $3.74 \mathrm{~g} \mathrm{~kg}^{-1}(+253 \%)$ in the $\mathrm{C}$ (Table 6), these increases being inversely proportional to those of the SDM (159\% and $37 \%$, respectively) (Table 3 ), for this same combination of treatments, indicating a dilution effect.

Table 6: $P$ content in soybean shoot dry matter influenced by the interaction between historical land use (NC: noncultivated; C: cultivated for long periods), P doses (P1 and P2) and mychorrizal inoculation (NI: non-inoculated; I: inoculated) in five Latosols (Oxisols).

\begin{tabular}{|c|c|c|c|c|c|c|c|c|}
\hline & \multicolumn{4}{|c|}{$1^{\text {st }}$ Cultivation - Simple interaction } & \multicolumn{4}{|c|}{$2^{\text {nd }}$ Cultivation - Double interaction } \\
\hline \multirow[t]{2}{*}{ Treatment } & & & & & \multicolumn{2}{|c|}{$P$ doses } & \multicolumn{2}{|c|}{ Inoculation } \\
\hline & \multicolumn{4}{|c|}{------------LVdft------------' } & P1 & $\mathrm{P} 2$ & $\mathrm{NI}$ & I \\
\hline $\mathrm{NI}$ & \multicolumn{4}{|c|}{$0.97 \mathrm{~b}$} & \multicolumn{4}{|c|}{ 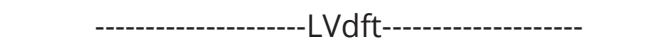 } \\
\hline I & \multicolumn{4}{|c|}{$1.53 \mathrm{a}$} & & & & \\
\hline NC & \multicolumn{4}{|c|}{$1.30 \mathrm{a}$} & $1.17 \mathrm{aA}$ & $1.24 \mathrm{aA}$ & $1.03 \mathrm{bB}$ & $1.38 \mathrm{aA}$ \\
\hline C & \multicolumn{4}{|c|}{$1.20 \mathrm{a}$} & $1.21 \mathrm{aA}$ & $1.34 \mathrm{aA}$ & $1.25 \mathrm{aA}$ & $1.30 \mathrm{aA}$ \\
\hline P1 & \multicolumn{4}{|c|}{$1.16 \mathrm{~b}$} & -- & -- & $1.15 \mathrm{aA}$ & $1.22 \mathrm{bA}$ \\
\hline \multirow[t]{2}{*}{ P2 } & \multicolumn{4}{|c|}{$1.34 \mathrm{a}$} & -- & -- & $1.13 a B$ & $1.46 \mathrm{aA}$ \\
\hline & \multicolumn{4}{|c|}{------------Double interaction--------------- } & & & & \\
\hline NC & $0.79 \mathrm{bB}$ & $1.41 \mathrm{bA}$ & $1.05 \mathrm{bA}$ & $1.15 \mathrm{bA}$ & $0.86 \mathrm{bB}$ & $1.25 \mathrm{bA}$ & $1.03 \mathrm{bA}$ & $1.08 \mathrm{bA}$ \\
\hline C & $1.06 \mathrm{aB}$ & $3.74 \mathrm{aA}$ & $2.14 a \mathrm{~B}$ & $2.66 \mathrm{aA}$ & $0.95 a B$ & $2.28 \mathrm{aA}$ & $1.58 \mathrm{aA}$ & $1.65 a \mathrm{~A}$ \\
\hline P1 & & & $0.83 \mathrm{bB}$ & $1.02 \mathrm{bA}$ & & & $0.86 \mathrm{bA}$ & $0.94 \mathrm{bA}$ \\
\hline \multirow[t]{5}{*}{ P2 } & & & $2.37 a B$ & $2.79 a A$ & & & $1.74 a \mathrm{a}$ & $1.79 \mathrm{aA}$ \\
\hline & \multicolumn{4}{|c|}{---------------Triple interaction------------- } & & & & \\
\hline & \multicolumn{4}{|c|}{--------------------'LVdfg--------------- } & & & & \\
\hline & \multicolumn{2}{|c|}{ P1 } & \multicolumn{2}{|c|}{ P2 } & & & & \\
\hline & $\mathrm{NI}$ & 1 & $\mathrm{NI}$ & 1 &.-- & -------- & dfg------- & \\
\hline NC & $0.68 \mathrm{bBy}$ & 0.97aBy & $0.92 \mathrm{bAx}$ & $1.33 a A x$ & $0.74 a \mathrm{~B}$ & $0.97 \mathrm{aA}$ & $0.77 a B$ & $0.94 \mathrm{aA}$ \\
\hline C & $0.77 \mathrm{bBx}$ & 1.14aAx & $0.88 \mathrm{bAx}$ & 1.12aAy & $0.74 a B$ & $0.90 \mathrm{aA}$ & $0.80 \mathrm{aA}$ & $0.84 \mathrm{bA}$ \\
\hline
\end{tabular}


Table 6: Continuation.

\begin{tabular}{|c|c|c|c|c|c|c|c|c|}
\hline & \multicolumn{4}{|c|}{$1^{\text {st }}$ Cultivation - Simple interaction } & \multicolumn{4}{|c|}{$2^{\text {nd }}$ Cultivation - Double interaction } \\
\hline Treatment & & & & & \multicolumn{2}{|c|}{ P doses } & \multicolumn{2}{|c|}{ Inoculation } \\
\hline P1 & & & & & & & $0.68 \mathrm{bB}$ & $0.80 \mathrm{bA}$ \\
\hline P2 & & & & & & & $0.89 a \mathrm{~B}$ & $0.98 \mathrm{aA}$ \\
\hline NC & $0.64 b B y$ & $0.78 a B y$ & $0.91 b A y$ & $1.54 \mathrm{aAx}$ & $0.87 a B$ & $1.03 \mathrm{bA}$ & $1.03 \mathrm{aA}$ & $0.88 \mathrm{bB}$ \\
\hline C & $0.79 b B x$ & $0.96 a B x$ & $1.36 a A x$ & 1.40aAy & $0.95 \mathrm{aB}$ & $1.25 \mathrm{aA}$ & $1.01 \mathrm{aB}$ & 1.19aA \\
\hline P1 & & & & & & & $0.95 \mathrm{aA}$ & $0.87 \mathrm{bA}$ \\
\hline \multirow[t]{4}{*}{ P2 } & & & & & & & $1.09 \mathrm{aA}$ & $1.20 \mathrm{aA}$ \\
\hline & & & & & \multicolumn{4}{|c|}{ Triple interaction } \\
\hline & & & & & \multicolumn{2}{|l|}{ P1 } & \multicolumn{2}{|l|}{$\mathrm{P} 2$} \\
\hline & & & & & $\mathrm{NI}$ & 1 & $\mathrm{NI}$ & 1 \\
\hline NC & $0.72 \mathrm{aBx}$ & $0.72 \mathrm{aBy}$ & $0.94 a A x$ & $0.99 a A x$ & $0.90 a A x$ & $0.64 b B y$ & $0.81 \mathrm{aAx}$ & 0.91 aAy \\
\hline C & $0.68 \mathrm{bAx}$ & $1.10 \mathrm{aAx}$ & $0.78 b A y$ & $0.98 \mathrm{aBx}$ & $0.74 b B y$ & $0.85 a B x$ & $0.89 \mathrm{bAx}$ & 1.10aAx \\
\hline
\end{tabular}

NC: non-cultivated; C: cultivated; P1: Low P dose; P2: High P dose; NI: non-inoculated; I: inoculated. In simple interaction, a and $\mathrm{b}$ compare the mean values within the treatments (inoculation, $\mathrm{P}$ dose, and historical land use). In double interaction, $\mathrm{A}$ and $\mathrm{B}$ compare the mean values horizontally, and $\mathrm{a}$ and $\mathrm{b}$, compare them vertically. In triple interaction, $\mathrm{A}$ and $\mathrm{B}$ compare the effect of $\mathrm{P}$ dose (horizontally, within the same historical land use and inoculation procedure), a and b compare the inoculation effect (horizontally, within the same P dose and historical land use, and $\mathrm{x}$ and y compare the historical land use effect (vertically, within the same $\mathrm{P}$ dose and inoculation procedure). Means followed by the same letters do not differ statistically by Tukey test at $5 \%$ probability.

In the second cultivation, the response to $\mathrm{P}$ increase in LAx was more pronounced in the cultivated soil, with the shoot $\mathrm{P}$ concentration increased from 0.95 to $2.28 \mathrm{~g} \mathrm{~kg}^{-1}(+140 \%)$ (Table 6). In this same soil (non-cultivated) there was an increase from 0.86 to1.25 $\mathrm{g} \mathrm{kg}^{-1}(+46 \%)$. An inversely proportional effect was also seen in the increase of soil P content on the shoot $\mathrm{P}$ concentration: to the increases in SDM of $139 \%$ and $51 \%$ (Table 3 ), in the $\mathrm{NC}$ and $\mathrm{C}$ corresponding to increases of $46 \%$ and $140 \%$ in the soybean shoot $\mathrm{P}$ concentration, respectively. The same was observed for $\mathrm{LVw}$, where increases of $32 \%$ and $19 \%$ in the SDM phosphorus concentration corresponded to increases of 88 and $508 \%$ in the SDM in NC and C, respectively. In the $\mathrm{LVw}$ and LVdft, the response to $\mathrm{P}$ has occurred only in the presence of inoculation.

In the first cultivation, inoculation had no effect on the soybean shoot P concentration for NC and LAx (Table 6). In these same soils, the effect of inoculation was much less than that of P. Although having occurred in LAx and LAd, not always the greatest soybean shoot $\mathrm{P}$ concentration occurred with the highest soil $\mathrm{P}$ content.
For LVw and LVdfg, the greatest soybean shoot $\mathrm{P}$ concentration occurred with the application of the higher $\mathrm{P}$ dose in the presence of inoculation in non-cultivated soils, while the greatest content in the soil occurred in the cultivated soil (Table 4). In LVdft, the effect of inoculation on the soybean shoot $\mathrm{P}$ concentration was greater than that from the application of the higher $\mathrm{P}$ dose. Thus, there is a tendency towards an increase of the relative importance of the mycorrhizae on the soybean shoot $\mathrm{P}$ concentration from the more kaolinitic to the more oxidic soils. The fact of inoculation having influenced the soybean shoot P concentration in the LVdft (Table 6), but not the SDM (Table 3), suggests an over consumption of $\mathrm{P}$.

In the second cultivation, in some cases, stimulating increased dry mass, inoculation also negatively affected the soybean shoot $\mathrm{P}$ concentration, which happened for the non-cultivated LAd that received the higher $\mathrm{P}$ dose (Table 6). Comparing the soybean shoot $\mathrm{P}$ values in LAx and LVdft, for the two cultivations, there is less influence of inoculation in $\mathrm{P}$ response for the second cultivation. 
In other study with sorghum and soybean cultivation, an exponential increase in the $\mathrm{P}$ concentration with $\mathrm{P}$ doses was observed in the presence of Glomus etunicatum inoculum. The $\mathrm{P}$ concentration increased by $48.2 \%$ in sorghum and by $49.3 \%$ in soybean (Bressan et al., 2001) at different $\mathrm{P}$ contents (10.4 to $\left.95.5 \mathrm{mg} \mathrm{kg}^{-1}\right)$. For soils cultivated with rice, inoculation with Glomus mosseae always contributed to greater shoot and root $P$ concentrations (Covacevich; Echeverría; Aguirrezabal, 2007).

In LAx, LAd and LVdft, the greatest accumulated P values $\left(1^{\text {st }}+2^{\text {nd }}\right.$ cultivations) occurred in the applications of the higher P doses in cultivated LAx $(96.34 \mathrm{mg}$ ) and with the lower dose of $\mathrm{P}$ in the presence of inoculated LAd and LVdft (36.06 and $78.01 \mathrm{mg}$, respectively), while the lowest occurred with the application of P1 in non-cultivated LAx soil (18.81 mg) and P1 in the absence of inoculation in LAd and LVdft (6.99 $\mathrm{mg}$ and $26.35 \mathrm{mg}$, respectively) (Table 7).

In LVw and LVdfg, the lowest accumulated P values were in non-cultivated P1 soils with inoculation, while the greatest occurred with $\mathrm{P} 2$ and inoculation. The response in the LAx, LAd and LVdft was greater in non-cultivated soil and in the absence of inoculation (Table 7), which is due to, in a manner, similar to that observed for the SDM, with the lowest soil P content. In the LVdft, the greater response to P occurred in the cultivated soil (Table 7) in which the $\mathrm{P}$ content was lesser than in the non-cultivated.

In LAx, there was no effect of inoculation when the P2 was applied (Table 7). In the same cultivated soil, the P content (111 $\mathrm{mg} \mathrm{dm}^{-3}$ ) (Table 4) inhibited the development of mycorrhizal fungi (Table 5), while in the non-cultivated soil, with a P content of $81 \mathrm{mg} \mathrm{dm}^{-3}$, there was colonization, probably due to that fact that many spores of mychorrhizae occurred in the uncultivated soil and not in the cultivated, but the effect of mycorrhizae on $\mathrm{P}$ uptake was not significant. Still, for the LAx, with the $\mathrm{P} 1$ dose, inoculation raised the accumulated $\mathrm{P}$ from 19.61 $\mathrm{mg}$ to $24.17 \mathrm{mg}(+23 \%)$. In LVdft and LAd the effect, of inoculation was greater with P1 dose, with accumulated $\mathrm{P}$ in LAd going from $6.99 \mathrm{mg}$ to $18.88 \mathrm{mg}(+170 \%)$ and from $27.57 \mathrm{mg}$ to $36.06 \mathrm{mg}(+30 \%)$ at the P2 dose. In LVdt, these increases were $103 \%$ and $54 \%$, respectively, with P1 and P2 (Table 7). The effect of the inoculation was greater in LVdfg under $\mathrm{NC}$ conditions, and, within this, under $\mathrm{C}$ conditions, greater with $\mathrm{P} 1$ than $\mathrm{P} 2$.

In the cultivated $\mathrm{LVw}$, there was no effect of inoculation and for $\mathrm{NC}$, the effect was greater with $\mathrm{P} 1$. It was thus observed, as with the SDM, an additional complementary effect between $\mathrm{P}$ dose and inoculation. The effect of a factor on the P uptake is always lesser in the presence of another factor.
Table 7: Total accumulated $\mathrm{P}\left(1^{\text {st }}+2^{\text {nd }}\right.$ cultivations) in soybean shoot dry matter influenced by the interaction between historical land use (NC: non-cultivated; C: cultivated for long periods), P doses (P1 and P2) and mychorrizal inoculation (NI: non-inoculated; I: inoculated) in five Latosols (Oxisols).

\begin{tabular}{|c|c|c|c|c|}
\hline \multicolumn{5}{|c|}{ Double Interaction } \\
\hline Treatment & \multicolumn{2}{|c|}{$\mathrm{P}$ doses } & \multicolumn{2}{|c|}{ Inoculation } \\
\hline & P1 & P2 & $\mathrm{NI}$ & I \\
\hline & \multicolumn{4}{|c|}{ 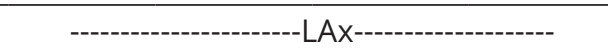 } \\
\hline NC & 18.81 bB & $76.93 \mathrm{bA}$ & $44.20 \mathrm{bB}$ & $51.54 \mathrm{bA}$ \\
\hline C & $24.97 \mathrm{aB}$ & $96.34 \mathrm{aA}$ & $62.27 \mathrm{aA}$ & $59.04 \mathrm{aA}$ \\
\hline P1 & & & $19.61 \mathrm{bB}$ & $24.17 \mathrm{bA}$ \\
\hline \multirow[t]{2}{*}{ P2 } & & & $86.86 \mathrm{aA}$ & $86.41 \mathrm{aA}$ \\
\hline & \multicolumn{4}{|c|}{----------------------LVdft----------------- } \\
\hline NC & $46.38 \mathrm{aB}$ & $67.37 \mathrm{aA}$ & $39.16 \mathrm{aB}$ & $74.58 \mathrm{aA}$ \\
\hline C & 33.42 bB & $61.24 \mathrm{bA}$ & $37.78 \mathrm{aB}$ & $56.88 \mathrm{bA}$ \\
\hline P1 & & & $26.35 \mathrm{bB}$ & $53.45 \mathrm{bA}$ \\
\hline \multirow[t]{2}{*}{ P2 } & & & $50.60 \mathrm{aB}$ & $78.01 \mathrm{aA}$ \\
\hline & \multicolumn{4}{|c|}{--' } \\
\hline NC & $7.87 \mathrm{bB}$ & $33.49 \mathrm{aA}$ & $17.93 \mathrm{aB}$ & $23.43 \mathrm{bA}$ \\
\hline C & $18.00 \mathrm{aB}$ & $30.14 \mathrm{bA}$ & $16.62 \mathrm{aB}$ & $21.52 \mathrm{aA}$ \\
\hline P1 & & & $6.99 \mathrm{bB}$ & $18.88 \mathrm{bA}$ \\
\hline \multirow[t]{5}{*}{ P2 } & & & $27.57 \mathrm{aB}$ & $36.06 \mathrm{aA}$ \\
\hline & \multicolumn{4}{|c|}{ Triple interaction } \\
\hline & \multicolumn{2}{|c|}{$\mathrm{P} 1$} & P2 & \\
\hline & $\mathrm{NI}$ & I & $\mathrm{NI}$ & 1 \\
\hline & \multicolumn{4}{|c|}{--------------------LVW-------------' } \\
\hline NC & \multicolumn{4}{|c|}{4.18 bBy 10.81 aBy 32.89 bAy 54.02 aAx } \\
\hline C & \multicolumn{4}{|c|}{16.70 aBx 21.02 aBx 48.92 aAx 48.83 aAy } \\
\hline & \multicolumn{4}{|c|}{----------------------LVdfg---------------- } \\
\hline NC & \multicolumn{4}{|c|}{$3.56 \mathrm{bBx} 16.02 \mathrm{aBx} 24.42 \mathrm{bAx} 49.82 \mathrm{aAx}$} \\
\hline C & \multicolumn{4}{|c|}{5.70 bBx 11.65 aBy 24.66 bAx 29.11 aAy } \\
\hline
\end{tabular}

NC: non-cultivated; C: cultivated; P1: Low P dose; P2: High P dose; NI: non-inoculated; I: inoculated. In double interaction, $A$ and $B$ compare the mean values horizontally, and $a$ and $b$, compare them vertically. In triple interaction, A and B compare the effect of $\mathrm{P}$ dose (horizontally, within the same historical land use and inoculation procedure), $a$ and $b$ compare the inoculation effect (horizontally, within the same $P$ dose and historical land use, and $x$ and $y$ compare the historical land use effect (vertically, within the same $P$ dose and inoculation procedure). Means followed by the same letters do not differ statistically by Tukey test at $5 \%$ probability. 


\section{CONCLUSIONS}

The soybean response, in terms of shoot dry mass production and $\mathrm{P}$ uptake, was influenced by the interaction between $\mathrm{P}$ doses, land use history, and mycorrhizal infections between the Latosols studied. The soil chemical and mineralogical attributes were determinants. Previous long-term soil cultivation reduced the response to $\mathrm{P}$ addition and mycorrhizal inoculation, and the magnitude of this reduction varied considerably between the soils. The response to $\mathrm{P}$ was lesser in inoculated plants. Response to mycorrhizal inoculation was greatly influenced by cultivation, with generally higher response in cultivated soils. Regardless of the soil, response to inoculation was greater when lesser $\mathrm{P}$ doses were applied.

\section{REFERENCES}

BRESSAN, W. et al. Fungos micorrízicos e fósforo, no crescimento, nos teores de nutrientes e na produção de sorgo e soja consorciados. Pesquisa Agropecuária Brasileira, 36:315-323, 2001.

CAMARGO, L. A. et al. Mapping of clay, iron oxide and adsorbed phosphate in Oxisols using diffuse reflectance spectroscopy. Geoderma, 251-252:124-132, 2015.

COMPANHIA NACIONAL DE ABASTECIMENTO - CONAB. Séries históricas. Available in: <http://www.conab. gov.br/conteudos.php?a=1252\&t=2>. Access in: June, 13, 2016.

COVACEVICH, F.; ECHEVERRÍA, H. E.; AGUIRREZABAL, L. A. N. Soil available phosphorus status determines indigenous mycorrhizal colonization of field and glasshouse grown spring wheat from Argentina. Applied Soil Ecology, 35:19, 2007.

COVACEVICH, F.; MARINO, M. A.; ECHEVERRÍA, H. E. The phosphorus source determines the arbuscular mycorrhizal potential and the native mycorrhizal colonization of tall fescue and wheatgrass. European Journal of Soil Biology, 42:127-138, 2006.

COZZOLINO, V.; MEO, V. D.; PICCOLO, A. Impact of arbuscular mycorrhizal fungi applications on maize production and soil phosphorus availability. Journal of Geochemical Exploration, 129:40-44, 2013.

EMPRESA BRASILEIRA DE PESQUISA AGROPECUÁRIA EMBRAPA. Manual de análises químicas de solos, plantas e fertilizantes. 2. ed. Brasília, Embrapa Informação Tecnológica, 2009. 627p.
EMPRESA BRASILEIRA DE PESQUISA AGROPECUÁRIA EMBRAPA. Manual de métodos de análise de solo. 2. ed. Rio de Janeiro, Embrapa Solos, 2011. 230p.

FITTER, A. H. Costs and benefits of mycorrhizas: Implications for functioning under natural conditions. Experientia, 47:350-355, 1991.

GERDERMANN, J. W.; NICOLSON, T. H. Spores of mycorrhizal Endogone species extracted from soil by wet sieving and decanting. Transactions of the British Mycological Society, 46:235-244, 1963.

GIOVANNETTI, M.; MOSSE, B. An evaluation of techniques for measuring vesicular-arbuscular mycorrhizal infection in roots. New Phytology, 84:484-500, 1980.

HART, M. M.; FORSYTHE, J. A. Using arbuscular mycorrhizal fungi to improve the nutrient quality of crops: Nutritional benefits in addition to phosphorus. Science Horticulturae, 148:206-214, 2012.

HRITOZKOVA, M. et al. Contribution of arbuscular mycorrhizal fungi in attenuation of heavy metal impact on Calendula officinalis development. Applied Soil Ecology, 101:57-63, 2016.

KÄMPF, N.; SCHWERTMANN, U. The 5M-NaOH concentration treatment for iron oxides in soils. Clays and Clay Minerals, 30:401-408, 1982.

LEIFHEIT, E. F.; VERBRUGGEN, E.; RILLIG, M. C. Arbuscular mycorrhizal fungi reduce decomposition of woody plant litter while increasing soil aggregation. Soil Biology and Biochemistry, 81:323-328, 2015.

LOPES, A. S.; GUILHERME, L. R. G. A career perspective on soil management in the Cerrado region of Brazil. Advances in Agronomy, 137:1-72, 2016.

MOREIRA, F. M. S.; SIQUEIRA, J. O. Microbiologia e bioquímica do solo. $2^{\text {a }}$ Ed. Editora UFLA, Lavras, 2006. 729 p.

MOTTA, P. E. F. et al. Adsorção e formas de fósforo em Latossolos: influência da mineralogia e histórico de uso. Revista Brasileira de Ciência do Solo, 26:349-359, 2002.

OLSEN, S. R.; WATANABE, F. S. A method to determine a phosphorus adsorption maximum capacity of soils as measured by the Langmuir isotherm. Soil Science Society of America Proceedings, 21:144-149, 1957.

PAULA, M. A.; SIQUEIRA, J. O. Efeito de micorrizas vesiculararbusculares no crescimento, nodulação e acúmulo de nitrogênio pela soja. Pesquisa Agropecuária Brasileira, 22:171-178, 1987. 
QIN, H. et al. Long-term fertilizer application effects on the soil, root arbuscular mycorrhizal fungi and community composition in rotation agriculture. Applied Soil Ecology, 89:35-43, 2015.

RAMOS, A. C. et al. An outlook on ion signaling and ionome of mycorrhizal symbiosis. Brazilian Journal of Plant Physiology, 23:79-89, 2011.

RODRIGUES, M. et al. Legacy phosphorus and no tillage agriculture in tropical oxisols of the Brazilian savanna. Science of the Total Environment, 542:1050-1061, 2016.

ROONEY, D. C. et al. Effect of arbuscular mycorrhizal colonization on the growth and phosphorus nutrition of Populuseur americana c.v. Ghoy. Biomass and Bioenergy, 35:4605-4612, 2011.

SALVAGIOTTI, F. et al. Nitrogen uptake, fixation and response to fertilizer $\mathrm{N}$ in soybeans: A review. Field Crops Research, 108:1-13, 2008.

SCHWERTMANN, U. Differenzienrung der Eisenoxide des Bödens durch Extraktion mit Ammoniumoxalat-lösung. Z. Pflanzenernahr. Und Bodenkd, 105:105-202, 1964.

SHARIF, M.; CLAASSEN, N. Action mechanisms of arbuscular mycorrhizal fungi in phosphorus uptake by Capsicum annum L. Pedosphere, 21:502-511, 2011.
SMITH, S. E. et al. Roles of arbuscular mycorrhizas in plant phosphorus nutrition: Interactions between pathways of phosphorus uptake in arbuscular mycorrhizal roots have important implications for understanding and manipulating plant phosphorus acquisition. Plant Physiology, 156:10501057, 2011.

WHABI, S. et al. Enhaced transfer of biologically fixed $\mathrm{N}$ from faba bean to intercropped wheat through mycorrhizal symbiosis. Applied Soil Ecology, 107:91-98, 2016.

$\mathrm{XIE}, \mathrm{X}$. et al. Effects of arbuscular mycorrhizal inoculation and phosphorus supply on the growth and nutrient uptake of Kandelia obovata (Sheue, Liu and Yong) seedlings in autoclaved soil. Applied Soil Ecology, 75:162-171, 2014.

$X U$, P. et al. Response of soils phosphorus required for maximum growth of Asparagus officinalis L. to inoculation of arbuscular mycorrhizal fungi. Pedosphere, 24:776-782, 2014.

ZARIK, L. et al. Use of arbuscular mycorrhizal fungi to improve the drought tolerance of Cupressus atlantica G. Comptes Rendus Biologies, 339:185-196, 2016.

ZHAO, R. et al. Arbuscular mycorrhizal fungi affect the growth, nutrient uptake and water status of maize (Zea mays L.) grown in two types of coal mine spoils under drought stress. Applied Soil Ecology, 88:41-49, 2015. 


\section{ERRATUM}

In the manuscript entitled "Long-term phosphate fertilization, mycorrhizal inoculation and historical land use influence on soybean growth and P uptake", with the DOI number: http://dx.doi.org/10.1590/141370542016404014216, published in the period Ciência e Agrotecnologia, 40(4)418-431, page 426:

Where it read:

Table 5: Mychorrizal colonization in soybean (\%) in the studied soils as a function of historical land use and $P$ doses in the two cultivations.

\begin{tabular}{ccccc}
\hline Soil & $\begin{array}{c}\text { Historical } \\
\text { land use }\end{array}$ & P dose & $\begin{array}{c}1^{\text {st }} \\
\text { cultivation }\end{array}$ & $\begin{array}{c}2^{\text {nd }} \\
\text { cultivation }\end{array}$ \\
\hline LAx & NC & P1 & 34 & 17 \\
LAx & NC & P2 & 46 & 29 \\
LAx & C & P1 & 0 & 0 \\
LAx & C & P2 & 50 & 20 \\
LAd & NC & P1 & 35 & 26 \\
LAd & NC & P2 & 56 & 3 \\
LAd & C & P1 & 24 & 20 \\
LAd & C & P2 & 49 & 20 \\
LVw & NC & P1 & 65 & 33 \\
LVw & NC & P2 & 51 & 3 \\
LVw & C & P1 & 10 & 14 \\
LVw & C & P2 & 30 & 16 \\
LVdfg & NC & P1 & 56 & 38 \\
LVdfg & NC & P2 & 39 & 9 \\
LVdfg & C & P1 & 54 & 21 \\
LVdfg & C & P2 & 62 & 7 \\
LVdft & NC & P1 & 47 & 53 \\
LVdft & NC & P2 & 65 & 36 \\
LVdft & C & P1 & 36 & 28 \\
LVdft & C & P2 & 53 & 29 \\
\hline NC: non-C & & 53
\end{tabular}

NC: non-cultivated; C: cultivated; P: doses of P (P2 - higher dose, P1 - lower dose).
Read:

Table 5: Mychorrizal colonization in soybean (\%) in the studied soils as a function of historical land use and $P$ doses in the two cultivations.

\begin{tabular}{ccccc}
\hline Soil & $\begin{array}{c}\text { Historical } \\
\text { land use }\end{array}$ & P dose & $\begin{array}{c}\text { 1st } \\
\text { cultivation }\end{array}$ & $\begin{array}{c}\text { 2nd } \\
\text { cultivation }\end{array}$ \\
\hline LAx & NC & P2 & 34 & 17 \\
LAx & NC & P1 & 46 & 29 \\
LAx & C & P2 & 0 & 0 \\
LAx & C & P1 & 50 & 20 \\
LAd & NC & P2 & 35 & 26 \\
LAd & NC & P1 & 56 & 3 \\
LAd & C & P2 & 24 & 20 \\
LAd & C & P1 & 49 & 20 \\
LVw & NC & P2 & 65 & 33 \\
LVw & NC & P1 & 51 & 3 \\
LVw & C & P2 & 10 & 14 \\
LVw & C & P1 & 30 & 16 \\
LVdfg & NC & P2 & 56 & 38 \\
LVdfg & NC & P1 & 39 & 9 \\
LVdfg & C & P2 & 54 & 21 \\
LVdfg & C & P1 & 62 & 7 \\
LVdft & NC & P2 & 47 & 53 \\
LVdft & NC & P1 & 65 & 36 \\
LVdft & C & P2 & 36 & 28 \\
LVdft & C & P1 & 53 & 29 \\
\hline
\end{tabular}

NC: non-cultivated; C: cultivated; P: doses of P (P2 - higher dose, P1 - lower dose). 